\title{
THE ASSOCIATION BETWEEN ESTRADIOL LEVEL, REMISSION, AND SURVIVAL IN BREAST CANCER PATIENTS AT DR. MOEWARDI HOSPITAL, SURAKARTA, CENTRAL JAVA
}

\author{
Widyanti Soewoto'), Ambar Mudigdo'), Teguh Aryandono3), \\ Paramasari Dirgahayu4)
}

\author{
${ }^{1)}$ Graduate School, Universitas Sebelas Maret \\ 2)Department of Anatomic Pathology, Faculty of Medicine, Universitas Sebelas Maret \\ 3)Department of Surgical Oncology, Faculty of Medicine, Universitas Gadjahmada \\ 4)Department of Parasitology, Faculty of Medicine, Universitas Sebelas Maret
}

\begin{abstract}
Background: The mortality rate of breast cancer patients was relatively high $80 \%-60 \%$ while the survival rate was only $<40 \%$. High estrogen levels and longterm exposure were associated with an increased risk of breast cancer. Recent studies have reported that estradiol can act independently and contribute to the risk of distant metastases in breast cancer patients with negative Estrogen Receptor (ER) tumors. The aim of this study was to estimate the estradiol effect on remission and survival in breast cancer patients in Dr. Moewardi Hospital, Surakarta, Central Java.

Subjects and Method: This was a cohort study conducted at the Department of Surgical Oncology, Dr. Moewardi Hospital, Surakarta, Central Java, from March to May 2015. A sample of 303 breast cancer patients was selected for this study and followed up until 3 years. The independent variable was estradiol level. The dependent variables were remission and survival. The data were collected by clinical examination and analyzed by Cox Proportional Hazard Model and Kapplan-Meier.

Results: High estradiol level decreased the possibility of remission $(\mathrm{HR}=0.31$; $95 \% \mathrm{CI}=0.09$ to $1.11, \mathrm{p}=0.003$ ) in breast cancer patients. Normal estradiol level increased survival $(\mathrm{HR}=4.03$; $95 \% \mathrm{CI}=1.94$ to 8.37 ; $\mathrm{p}<0.001)$.

Conclusion: High estradiol level decreases the possibility of remission, while normal estradiol level increases survival in breast cancer patients.
\end{abstract}

Keywords: remission, survival, estradiol, breast cancer

\section{Correspondence:}

Widyanti Soewoto. Graduate School, Universitas Sebelas Maret, Jl. Ir. Sutami No. 36 A, 57126, Surakarta, Central Java. 